\title{
REL Gene
}

National Cancer Institute

\section{Source}

National Cancer Institute. REL Gene. NCI Thesaurus. Code C17084.

This gene is involved in transcriptional regulation and signal transduction through the nuclear factor kappa B NFKB signal transduction pathway. 